\title{
THE PROBLEMS OF SPACE AND TIME IN LITERATURE
}

\author{
Yulchiyev Qahhor Vahobovich \\ Doctor of philosophy in philological sciences, \\ Ds candidate
}

Article DOI: https://doi.org/10.36713/epra3968

\begin{abstract}
ANNOTATION
While the creativity artistically realizes the existence, there is a need to percept the world through the time and space, which has been expressed by the different views since the ancient times. Having studied the thoughts of Zoroaster (Avesto), Plato, Aristotle, Abu Nasr Farabiy, Beruniy, Abu Ali Ibn Sino, Abu Khamid Gazali, Najmiddin Kubro and Immanuel Kant, the author expressed his opinion to their views on the integrity of the time and space in literature.

KEY WORDS AND EXPRESSIONS: poem, fiction, artistic space, “Avesto”, “Khindustan”, Zoroaster, Beruniy, Plato, Aristotle, Kant.
\end{abstract}

\section{INTRODUCTION}

Being aware of the existence, the human visualizes it within the space and time. Indeed, the life of any living creature, mainly the human, occurs in the real time and place. This matter can be clearly and vividly seen in the novel, drama and tragedy. There were some efforts to solve the problem in the epic and lyrically epic Uzbek literature, while less attention was paid to it in the poetry.

\section{MATERIALS AND METHODS}

Approaching to Aristotle's view “...the elements turned to be something general, as everything similar, being unique and simple by its nature, resides in all or many objects"[6.163], it is possible to substantiate the existence of the space and time in the poetry as the important elements. The time and period (in some degree chronotopic) are universal with the artistic world similar to them. Thus, it is natural, if the time and space in the lyrical poetry are close by their nature to the time and space in the dramatic and epic works.

It is important to emphasize that being a general philosophical category, a notion of the space and time in belles-lettres differ from the chronotop. "Being an important description of the artistic image, the artistic time and artistic space provide the holistic perception of the artistic reality and forms the composition of the work. The word art belongs to the group of the dynamic temporary arts (in comparison with the plastic space art). However, the literary-poetic image, formally dilating in the time (as the sequence of the text), reproduces the spatial-temporal picture of the world by its contents in the symbolized ideological value aspect [13.1174].

The scientist illustrated three features of the artistic time and artistic space. The first feature is the general characteristics of the image; the second, the means, which provide the unity of the work; the third, components of the composition of the work.

This matter has been studied for a long time in the philosophical disciplines. Zoroaster, Plato, Aristotle, Beruniy, Gazzaliy, Kant debated about the space and time, their place in the human civilization. For example, "At the moment, when all the living thing appeared, seeing you at the moment of bringing to the book of all the actions and words done during the life, I realized that you will give the gift of the goodness to good people, the gift of the badness to bad people, I knew you as pure" was written in the sacred book "Avesto" [4.53].

In the given passage Zoroaster showed the existence of the real border of the word (the moment, when all the living appeared). The word лахза means the moment and space, when all the living being appeared, it is relevant to chronotop. It is understood by Avesto, that before creating the world another world existed and our ancient predecessors realized that the space had several layers or it was unlimited.

"I summoned the words, before creating the blue sky, before the water, the earth, the vegetation, before the motions in the material world, before the birth of the two-legged man, before the sun, before creating Amposipands" [4.136].

Thus, the world, where we live, was created in another world, which is impossible to realize by the thought and mind of the person, that the space was created in one corner of the unlimited space, while the time considered the category, which shows all the events in it.

Considering that Avesto was a religious source, the discussions about the space and time in it can be met in the other religious books too. It can be said that 
the world has several layers, the bases of them is the Creator. The ideas of Zoroaster that the space is primary, while the time in it is secondary can be traced back to the ancient times.

The forms of chronotop as the human, a ground, a sky, a mountain, the thoughts about the different lyrical works are met. Especially, the thoughts about multileveled world were developed in the creations of the Middle Age scientists and the representatives of Tasawwuf ${ }^{1}$ literature. Mainly, while investigating the religion of Indian people, creation of the human and world, the measure of the space and time, Beruniy showed the great differences between the Arab Muslim world and Greek culture.

The scientist N.Komilov cites about the philosophy of Tasawwuf: "Regarding the world as the creation of the single Almighty, explaining the world as the mirror of the Allah, considering all the beauties and power came from the God, imagining the Being in the romantic colours and poetic symbols, which is in the perpetual motion under the influence of the divine light - it is a Poetry" [11.155].

The ideas of regarding the world as the great space and its Creator as unique cannot be met in the Indian scriptures.

It should be also mentioned from "Avesto" and related to the matter of the literary criticism, which is the object of the recent research and linked with the minor lyrical genres. It is mentioned that the poem, consisting of only one line, exists in the contemporary poetry. One-line poem was called in the ancient times 'toso', which denotes two meanings in Pahlavi language. The first meaning of the word 'toso' means the song, the second 'one-line poem' in Avesto 'afoman' or 'pag'mon' [3.598]. Thus, the one-line poem also existed in the ancient times $\mathrm{BC}$ and depicted the definite time.

Plato wrote in his work "State": the poets can say whatever they want, but it is a novel about the past, present and future [7.107]. Here the idea about the space and time of the artistic work is given. The notion of the time is broader and writers cannot pass the real time borders. Developing these ideas, the interlocutors told to leave the types of the literary works, which inspire the people to goodness and truth, bringing people brave and noble; and withdraw the parts, which evoke the panic, bad and rude feelings in people. And it shows the opportunity of revealing the unity of the space and time, created by the writer.

The ideas of Aristotle on the problems of unity of the space and time are distinguished by the scientific nature and clarity. Mainly, "the tragedy can be within the day of a little more, while the epopee is not restricted by the time" [5.26].

\footnotetext{
${ }^{1}$ Mystic-ascetic trend in Islam, which stipulates ethical and moral precepts of religious people
}

If the main idea is about the differences of the tragedy and epopee, it can be also mentioned that there are two reasons for the origin of the art of the Poetry, and both of them are natural. Firstly, the simile and reduplication is a feature, peculiar to the person from the childhood... the simile as the harmony and rhythm are natural in people's character [5.24]. If the person can create the work, like a nature; it is natural to say, he can create artistic time and artistic space as the space in nature and the time in life. Thus, Aristotle's thought represents that each literary work, whether it is a novel, drama or minor poetic work; all of them reflect the part of the major time; being influenced by the world, the author can create the small part of the world in his creative laboratory.

Kwint Horaziy Flakk criticizes the extension of the composition and paying an excessive attention to the description of the space in the works "after the initial moment, which promises the most important thing, most of the time is devoted to the description of the shadows of the fences, Diana's alcove and winding brook, flowing in the beautiful fields, or the Rheine river, or the rainbow, seen in the blue sky in different colors in order to attach the pomposity. But it is inadequate here" [14.127]. Hence, the description of the space in belles-lettres should be relevant to the contents of it.

Michael Psell compares creating the art work with a house construction: "he reminds that it is worth beginning to construct the house not from laying the house footing, nailing, building the walls and housetop, but from decorating with the patterns and stones" [14.135]. As he states, the grounds of the house should be an exactly measured space. Another stage is building the walls, which are compared with the space; then, laying the housetop, so that the decors cannot be removed from external cold and moisture. This way, the complicated space can turn into the masterpiece. By this simile he illustrated the importance of the space in the composition of the work.

Abu Nasr Farabiy emphasizes the essence of the existence or the Creator on the bases of the Being and existence of the time motion in the space and its hidden form: "Perhaps cognition is a feature of a person or the influence of the person. If the cognition is the influence of the features of the person, its essence includes the motion to the perfectness appeared under the influence of its nature" [2.57].

Considering, that the person is a minor world, the notions of the time and the space in the major world, mainly, the things occur in the internal world of the person.

Developing his ideas, the scientist substantiated that all the things in this world are in the motion and occur, expand in the definite time. "I confirm that the substance is in motion by its nature, which consists of three types: high velocity, low velocity and medium velocity motion. There is a need to develop the science to study and compare the 
measure of the velocity: the science on the celestial motion" [2.175-176].

It is obvious from Farabiy's thoughts, that the substance is the objective reality, which is in simultaneous motion in space and time. Thus, it can be stated that the entity or chronotop is mentioned here. However, it could be said that the entity or the Creator is accepted as the chronotop.

There is also a proof on the hidden time and period by Gazaliy: "You should know, that in order to form the third knowledge there should be the two other knowledge in the mind. If a person prefers this world, considers the Hereafter above this world, there are two ways for it: the first, hearing about the Hereafter from the others, he follows it and confirms not realizing the essence of it. And it is called "reiteration", but it is not the knowledge. The second way is the exact knowledge about the Eternity. He will completely realize that the Hereafter is eternal. In the result of it, he can pass to the third knowledge. The preference of choosing the Hereafter comes on total understanding of the two previous types of knowledge" [3.4]. The scientist cites several spaces here: the heart (internal space), this world (material, visible space), the Hereafter (the other world); claiming that on the bases of them there is another, the fourth space. Thus, the idea of multileveled space, which was mentioned above has also taken the place in the views of Gazali.

Some contradictory views can be seen in the study of the time and the space as the changeable ascendant positions of the time and space. For example, the German philosopher Immanuel Kant confirms that the things can belong to the space and the sensory imagination of them is purely subjective and the space prevails in revealing the things and events [10.13].

Indeed, Kant appreciated the primary position of the space in esthetic perception of the existence. However, in his ideas the interrelated features of the space and time were not mentioned. It can be inferred that the person imagines the existence through the coordinates of measure of this world. It can be understood that the sequences of events or the action of the materialistic world can be measured by time.

As Najmiddin Kubro proposed in the theory of "Ofoq va anfusa" that the person is a minor world, who reflects the features of the major world [11.174].

In the literature of Tasawwuf the notions of the time and the space is mostly regarded as the formation of the spiritual, hidden views, observing the major world as the existence, the large space, while the person is a minor world.

Abu Reikhan Beruniy determines the integrity of the space and artistic information and the differences of their opportunities as the following: "The utterance 'it is preferable to see rather than to hear' is quite correct. When the person sees with his own eyes, he can rightly accept the situation at the time and place when it is happened. If there are no uncertainties in delivering the information, it can be more feasible. However, being limited by the objective existence the reality cannot transcend the definite time, while the information can involve the periods of what is happened before and after the event" [8.57]. Being at the place and seeing the event, the author delivers the artistic information by preceding and accomplishing moments, furthering the increase of the opportunities of the time and space units. Hence, the effects of the lyrical poem in the form of the artistic information will increase.

Beruniy depicts the views of the Greek, Indian and Muslim scientists about the time and space and shows his own attitude to them. "There are living creatures in the world; consequently, there must be a spirit. There are rational beings among the livings and also the art, carried to the perfectness. Consequently, there should be a Creator, a wise and knowledgeable, making everything perfect and correcting to the best, gifting the power of the mind to reach the salvation. However, there are such thinkers, who ponder the eternity and time as a single notion, while finiteness the property of the motion, counting the time out" [8.288]. Thus, Beruniy subscribes to the opinion about the existence of the wise people and the perfect art, as well as the existence of the spirit in the animate being.

Beruniy expresses his view on the scientific opinions of his contemporaries about the space and time. "According to the doctrine of the ancient Greeks, the five things existed eternally: the Creator - let glory be upon him! - and the universal spirit, the primary substance, the abstract space and the abstract time. He created his own doctrine on the five things, which fundamentally based on them. He distinguished the time and duration" [8.288].

Though, the world creating is mentioned here, the bases of it are closer to our research, the scientist distinguishes forming the world by the time and space, Roziy states knowing the differences between the time and extent. Beruniy considers the time and extent separately in order to attach importance to the motion and action on the bases of the time and extent. As the world is an enormous space, the time reveals through the action, event and occurrence.

Abu Ali Ibn Sina (Avicenna) mentioned about the time in fiction in the oriental poetry: "Usually the words of image and dreams fulfill much, some of them are related to the time outspoken and its duration. The duration of the time is a weight" [1]. If the attention is paid, the scientist meant that the event in the poetry was mostly related to the time. The time is a definite measure, which shows the appropriateness to the poem's measure. However, there is no view about the space, the event and the contents.

It is seen from the above-mentioned, that the study of the space and the time has a long history. The oriental scientists have the same opinion about the relations of time and space, their compatibility, interpenetration, and that all the things existed on the bases of the two of them. 
The problem of chronotop in Alisher Navoiy works and the forms of it in the work "Days gone by" are worth attention in the research of U.Jurakulov [9]. The scientist successfully reveals the chronotop from the standpoint of the historical poetry. Furthermore, the Russian scientist M.Bakhtin made his contributions to the revealing of the problem. M.Bakhtin particularly emphasizes the peculiar features of chronotop in the Uzbek literature. He distinguishes the two types of chronotop in "Lison-ut-tayr" and made an effort to depict the features of the genre "Khamsa". He ponders about the religious, mythological forms of revealing the world, the notions of the universe and chaos, which prove the knowledge about the universe as the chronotop and the existence of the world and human chronotop in artistic reflection. Especially, the cronotop and its national, Islamic values are properly substantiated.

There are various thoughts about the unity of the time and space, in some cases they should also be explained through motion and reflection of the world. It seems to be unfeasible, as the artistic time and the artistic space can be considered the componential part of both artistic thought and the plot. Indeed, the people exist within the time and space in the life and percept the world spiritually, rationally and emotionally. However, the artistic time and the artistic space can be revealed through realization of the artistic thought in the forms of the action of the time, thoughts and debates. Thus, the artistic time and the artistic space can be the compositional bases of any work, the other elements as the plot, text forming, details and image exist in the time and space. Supposing there are no time and space, there will not be abovementioned elements.

\section{CONCLUSIONS}

The following conclusions on the development of the space and time in the history of the artistic thought can be cited:

1. The problem of the time and space as the philosophical categories is considered to be the object of the research in literary criticism. Therefore, the historical developments of the time and space along with the approaches of the eastern and western scientists have been compared. The results show the identity of their views, which complement each other's theories.

2. The views of some scientists in perception of the world illustrate that the space is primary and the motion of the events in it is secondary.

3. As the sources show, the scientists share the similar views on the two prevailing features of the time and space: the first, the time and the space are interrelated categories; the second, they extend in the definite sphere and can be in constant motion, or in logical sequence.

4. According to the different approaches there are several forms of the time and space as the real time and space, hidden time and space, religious time and space.

\section{REFERENCES}

1. Абу Али ибн Сино. шеър санъати http://www.eadabiyot.uz.adabiyotshunoslik (Uzbek Language)

2. Абу Наср Форобий. Фозил одамлар махри (Танланган асарлар). - Тошкент: Абдулла Қодирий номидаги халқ мероси нашриёти, 1993. - 224 б. ( Uzbek Language)

3. Абу Хомид Ғаззолий. Ихёу улумид-дин. Тафаккур китоби. - Тошкент: Тошкент ислом университети, $\quad$ www.ziyouzcom.uz. ( Uzbek Language)

4. Авесто: тарихий-адабий ёдгорлик / Н.Жўраев; таржимон А. Махкам. - Тошкент: Ғафур номидаги нашриёт-матбаа ижодий уйи, 2015. -732 6. ( Uzbek Language)

5. Арасту. Поэтика. Ахлоқ̧и кабир. Риторика. Тошкент: Янги аср авлоди, 2012. - 352 б. ( Uzbek Language)

6. Аристотель. Метафизика. Перевод с греческого П. Д. Первова и В. В. Розанова. - М.: Институт философии, теологии и истории св. Фомы, 2006. - 232 c. (Russian Language)

7. Афлотун. Давлат. - Тошкент: Янги аср авлоди. 2015. - 464 б. (Uzbek Language)

8. Бируни А. Индия: Пер. с араб./Репринт с изд. 1963 г. - М.:Ладомир, 1995. - 727 c. (Russian Language)

9. Журақулов У. Назарий поэтика масалалари: Муаллиф. жанр, Хронотоп. -Тошкент: Ғафур Хулом номидаги нашриёт матбаа уйи, 2015. 356 б. ( Uzbek Language)

10. Кант, Иммануил. Критика способности суждения. - М.: Искусство, 1994 -365 с. (Russian Language)

11. Комилов Н. Тасаввур. Биринчи китоб. Тошкент: Ёзувчи. - 272 б. (Uzbek Language)

12. Комилов Н. Тасаввуф. Иккинчи китоб. Тавхид асрори. - Т.: Ғафур Ғулом номидаги адабиёт ва санъат, 1999. -208 б. ( Uzbek Language)

13. Литературная энциклопедия терминов и понятий / Под ред. А.Н.Николюкина.- М.: НПК «Интелвак», 2001. - 1600 стб. (Russian Language)

14. Қуронов Д., Рахмонов Д. Ғарб адабийтанқидий тафаккури тарихи очекрлари. Тошкент: Фан, 2008. - 276 б. (Uzbek Language) 